\title{
Copepod growth and development around South Georgia: relationships with temperature, food and krill
}

\author{
Rachael S. Shreeve*, Peter Ward, Mick J. Whitehouse \\ British Antarctic Survey, Natural Environment Research Council, High Cross, Madingley Road, \\ Cambridge CB3 0ET, United Kingdom
}

\begin{abstract}
Measurements of egg production rates (EPR) and growth of the early stages of 2 of the Southern Ocean biomass dominant copepods, Calanoides acutus and Rhincalanus gigas, were made over the course of 4 consecutive summer cruises which were carried out in the vicinity of South Georgia. For both species, EPR was found to be weakly but significantly related to chlorophyll a (chl a) although for $C$. acutus it was below maximum levels recorded in spring. Juvenile mass specific growth rates $(g)$ were found to be body mass, stage and species dependent. Mean $g$ for $C$. acutus stages CII to CIV decreased from 0.24 to 0.14 , and for $R$. gigas stages CI to CIII from 0.06 to 0.04 . Overall, values for both species were within the range predicted by recent global models of copepod growth. Neither stage duration nor $g$ varied systematically with either temperature (mean, 0 to $60 \mathrm{~m}$ ) or food (chl $a, 0$ to $60 \mathrm{~m}$ ). However, carbon mass of nearly all species stages was negatively and significantly related to silicate levels $\left(\mathrm{mol} \mathrm{m}^{-2}, 0\right.$ to $60 \mathrm{~m}$ ), suggesting the positive effect of past production levels. Ordination of zooplankton species occurrence by station across the survey area indicated that changes in abundance were more pronounced than changes in species composition, and that variation in total copepod abundance was also well explained by silicate levels. Our study indicated that changes in EPR, carbon mass and abundance of copepod populations at South Georgia were all strongly regulated by local primary production. Variation of chlorophyll biomass appeared largely dependent on temperature, rather than grazing pressure exerted by either copepods or krill. Krill at South Georgia were more abundant in colder, silicate replete waters and their presence is presumed to be governed by factors operating at the large scale. In contrast, copepod abundance appeared to differ in response to smaller scale variation in the environment and was linked through silicate to factors determining phytoplankton growth. In turn, chl a concentration was strongly and positively related to habitat temperature. This suggests the importance of the physical environment rather than grazing as ultimate factors controlling phytoplankton biomass in this productive ecosystem.
\end{abstract}

KEY WORDS: Rhincalanus gigas · Calanoides acutus · Copepod · Development · Growth · Krill · South Georgia

Resale or republication not permitted without written consent of the publisher

\section{INTRODUCTION}

The island of South Georgia lies in the northern Scotia Sea within the ice-free region of the Antarctic Circumpolar Current (ACC). Throughout much of its extent the ACC is oligotrophic and exemplifies the High Nutrient Low Chlorophyll (HNLC) system typical of much of the Southern Ocean. Production within this zone is generally low and is highly seasonal, occurring after rapid near-

*E-mail: rssh@nerc-bas.ac.uk surface stabilisation of the water column in SeptemberOctober (Tréguer \& Jacques 1992, Longhurst 1998). In stark contrast, the ocean in the vicinity of South Georgia can be extremely productive. Chlorophyll a (chl a) can attain concentrations $>20 \mathrm{mg} \mathrm{m}^{-3}$ (Whitehouse et al. 1996) and satellite-derived ocean colour measurements indicate that extensive phytoplankton blooms can develop around the island from November onwards and persist throughout the summer (Atkinson et al. 2001). Associated with this elevated phytoplankton production, zooplankton biomass often reaches levels considerably higher than in the rest of the ACC (Mackintosh 1934, 
Ward et al. 1995, Atkinson et al. 1997). Nonetheless there is considerable seasonal variability in oceanographic conditions around South Georgia. Surface temperatures rise from $\sim 0^{\circ} \mathrm{C}$ in winter to $\sim 4^{\circ} \mathrm{C}$ in late summer, while silicate concentrations fall from $\sim 25$ to $30 \mathrm{mmol} \mathrm{m}^{-3}$ in winter to $<1.0 \mathrm{mmol} \mathrm{m}^{-3}$ in some summers (Whitehouse et al. 1996, 2000). The timing and magnitude of phytoplankton blooms varies (Atkinson et al. 2001) as does zooplankton biomass, which is typically dominated by varying proportions of Antarctic krill Euphausia superba and copepods.

Huntley \& Niiler (1995) have noted the localised nature of productive regions in the Southern Ocean and have emphasised the control that physical processes, in particular rates of advection, can exert on zooplankton population dynamics. In this context, recruitment of krill does not occur within the South Georgia region (Marr 1962, Ward et al. 1990) and its presence reflects immigration from up-current areas. In contrast, copepod recruitment takes place throughout the region and is thought to benefit from locally enhanced production levels (Atkinson et al. 2001).

Our understanding of copepod population dynamics at South Georgia and elsewhere in the Southern Ocean is still however largely fragmentary. Our view of copepod lifecycles is largely based on spatially and temporally averaged stage frequency data for a restricted number of species (e.g. Atkinson et al. 1997, Ward et al. 1997) and in comparison to krill, little in situ work on copepod growth and development has taken place.
Four recent summer cruises to South Georgia have allowed us to investigate egg production and in situ growth rates of the younger copepodite stages of 2 important Southern Ocean species, Calanoides acutus and Rhincalanus gigas. In undertaking this study, we wished to understand how copepod growth varied with respect to species and its relationship to key environmental variables. We have therefore examined our data, including overall copepod abundance, in relation not only to temperature and food availability but also with krill biomass, which has been suggested as a major factor in the control of copepod populations (Atkinson \& Snÿder 1997, Atkinson et al. 1999). In so doing, we wished to form a clearer picture of the factors which are potentially important controls on copepod population dynamics in the region.

\section{MATERIALS AND METHODS}

Study location and sample collection. During 4 consecutive austral summers (1995/6 to 1998/9) between mid-December and late January, a multi-disciplinary study of physical and biological variability of the South Georgia marine ecosystem was carried out. Two areas were investigated, one to the northwest (Western Core Box, WCB) and the other to the northeast (Eastern Core Box, ECB) of the island (Fig. 1). During each cruise, 4 transect pairs, each $80 \mathrm{~km}$ long, were run in each box, perpendicular to the shelf break. Acoustic

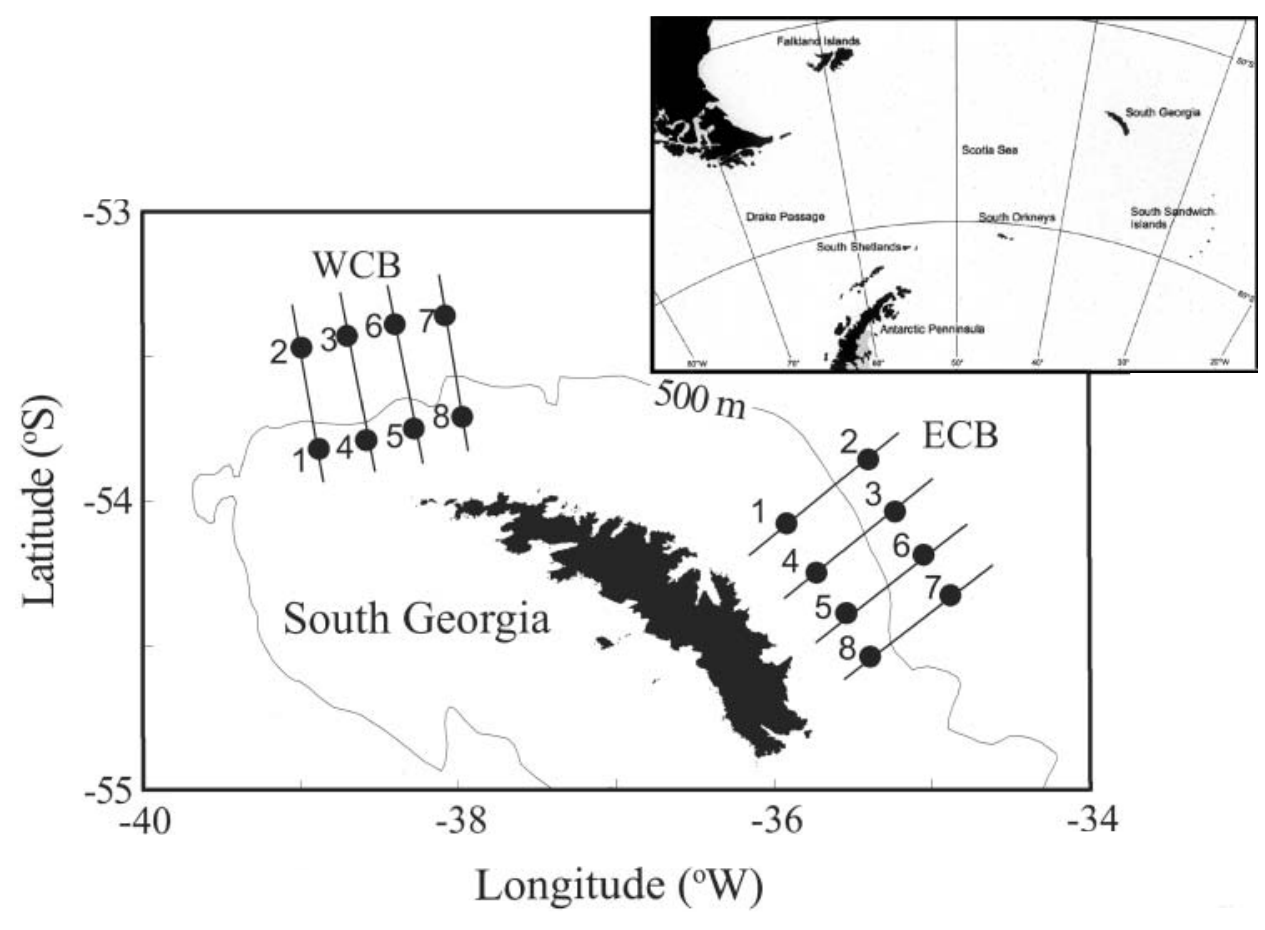

Fig. 1. Map of study area showing South Georgia, the $500 \mathrm{~m}$ isobath, and transect lines. : station positions. WCB and ECB: Western and Eastern core boxes respectively. Stations numbered in order they were sampled. Shaded area shows the broader geographical area of the study 
surveys were carried out along these transect lines during daylight to determine the biomass of Antarctic krill Euphausia superba; details of the survey methods used and biomass estimation are given by Brierley et al. (1997, 1999). For our purposes, krill biomass estimates are expressed as $\mathrm{g}$ wet mass $\mathrm{m}^{-2}$ integrated over the top $250 \mathrm{~m}$ and represent a mean density calculated $5 \mathrm{~km}$ either side of the station position on each transect (see below). Twenty kilometres from both the inshore and offshore ends of the second of each transect pair, stations were established to study the water column in more detail (Fig. 1). All station-based measurements were made between dusk and dawn.

Temperature, chl $\boldsymbol{a}$ and nutrient profiles. A 12 bottle General Oceanics rosette system with a CTD (conductivity temperature and depth profiler) was deployed to $200 \mathrm{~m}$ depth (or near bottom if shallower) at the inshore stations and to $1000 \mathrm{~m}$ at those offshore. From these casts, temperature and salinity profiles at 2 dbar intervals were derived, covering the depth range from $200 \mathrm{~m}$ to the surface. Water bottle samples were taken at standard depths of 6, 20,40 and $60 \mathrm{~m}$. Discrete salinity analyses were performed according to the method in Brandon et al. (2000). Chl a was measured fluorometrically (Parsons et al. 1984), and silicate was measured colorimetrically (Whitehouse 1997).

Zooplankton sampling. Zooplankton were sampled at each station using a Bongo net fitted with a motion compensated spring designed to minimise damage to the copepods during collection. The Bongo frame was equipped with a $200 \mu \mathrm{m}$ mesh net of $61 \mathrm{~cm}$ diameter mouth opening and a $5 \mathrm{l}$ non-filtering cod end. The net was hauled vertically from $200 \mathrm{~m}$ to the surface at 10 to $13 \mathrm{~m} \mathrm{~min}^{-1}$. Once on board, samples were diluted in approximately 201 of surface seawater. Copepods were then sorted within $3 \mathrm{~h}$ at ambient temperature $\left( \pm 1^{\circ} \mathrm{C}\right)$ for experimental work and the residue preserved in $4 \%$ formaldehyde in seawater.

Copepod abundance. The preserved Bongo samples were subsampled with a Folsom plankton splitter and analysed under a dissection microscope. All copepod taxa were enumerated and copepodite stage frequency determined for the biomass dominant copepods. Mean stage of the populations of Rhincalanus gigas and Calanoides acutus were calculated according to Ward et al. (1996).

Egg production rate (EPR) experiments. At each station, where abundance permitted, 3 groups of 10 adult females of Rhincalanus gigas and Calanoides acutus were sorted from the samples. Individuals were then incubated according to the method of Ward \& Shreeve (1995).

At the end of the incubation period eggs were removed and counted and females used for dry (DM) and carbon mass (CM) analyses (see below). Mass specific growth rate for females $(g)$ was assumed to be linear, and was defined as a measure of the amount of egg carbon produced per day, divided by female body CM (Hirst \& Lampitt 1998). Egg CM was estimated using DM reported in Ward \& Shreeve (1995) assuming a CM to DM of $45 \%$.

Moulting rate (MR) experiments. At each station, the dominant copepodite stages of Rhincalanus gigas and Calanoides acutus were sorted under a dissection microscope and removed for moulting rate studies, using the method of Shreeve \& Ward (1998). Moulting rates were calculated using the equation in Shreeve \& Ward (1998). Stage durations (d) were calculated as the reciprocal of the moulting rates. Confidence intervals $(95 \%)$ for the sample fraction were constructed from statistical tables (Neave 1981) and these were transformed to reciprocals to express them as a function of time.

Dry and carbon mass analyses (DM and CM). Individuals from the experiments were rinsed in $4 \%$ ammonium formate solution, blotted dry and then placed in pre-weighed ultra light-weight tin foil capsules. To facilitate accurate measurement of DM, younger copepodite stages were pooled within their stage as follows: 20 individual CII Calanoides acutus, 10 each of C. acutus stages CIII and CIV and Rhincalanus gigas stages $\mathrm{CI}$ and $\mathrm{CII} ; 5$ of $C$. acutus stages $\mathrm{CV}$ and $\mathrm{CVI}$ females and $R$. gigas stages CIII to $\mathrm{CV}_{\text {; }}$ adult female $R$. gigas were treated individually. These samples were then frozen at $-80^{\circ} \mathrm{C}$ and subsequently dried at $60^{\circ} \mathrm{C}$ on board ship within $1 \mathrm{wk}$ of the experiment. In UK laboratories, DM was measured on a Mettler MT5 balance to an accuracy of $\pm 1 \mu \mathrm{g}$. Whole samples were then analysed for carbon, hydrogen and nitrogen content using a Fisons EA 1108 elemental analyser, and calibration curves were constructed using the standard acetanilide.

Instantaneous growth rates $(\boldsymbol{g})$. These were calculated from the measured carbon masses and stage durations for moulting juvenile stages, using the equation:

$$
g=\left(\ln \mathrm{W}_{i}+1-\ln \mathrm{W}_{i}\right) / t
$$

where $\mathrm{W}_{i}$ is the mean mass of stage $i(\mu \mathrm{g} C), \mathrm{W}_{i}+1$ the mean mass of the subsequent stage $(\mu \mathrm{g} \mathrm{C})$ and $t$ is the estimated stage duration (d) (Shreeve \& Ward 1998).

Data analysis. Least-squares linear regressions were used to examine the relationship between concurrently measured environmental parameters and variation in Rhincalanus gigas and Calanoides acutus EPR, stage duration, CM, $g$ and abundance. Since both temperature and food are linked to planktonic growth processes, we used mean temperature in the top $60 \mathrm{~m}$, and minimum temperature in the top $200 \mathrm{~m}$ as vari- 
ables. The food environment was characterised by chl a concentration, which serves as an indication of phytoplankton abundance. We also considered nutrient depletion as a proxy for the extent of the recent (days to weeks) phytoplankton productivity. We specifically chose silicate because the products of its biological use are re-mineralised far more slowly than any other commonly measured nutrients such as nitrate or phosphate, and the phytoplankton around South Georgia is dominated by diatoms which are reliant on silicate. Summer nutrient dynamics are also subject to non-phytoplankton losses from, or gains to the system brought about by island-shelf modification (Brandon et al. 2000), the influence of high nutrient waters from the Southern ACC Front (SACCF) (Thorpe et al. in press) and possibly also the Weddell Sea Confluence (Brandon et al. 1999). Therefore, we examined vertical nutrient distribution in relation to $1000 \mathrm{~m}$ temperature/salinity profiles.

Despite apparently large variability in surface and near-surface water mass properties, consideration of the deeper water column indicated that South Georgia was north of the SACCF (in the ACC zonation) throughout the sequence of measurements, according to the definitions of Orsi et al. (1995). Furthermore, typical island run-off examined during the present study had a negligible diluent effect on nutrient concentrations ( $<0.4 \%$; Brandon et al. 2000).

We confined most of our comparisons of the biological data to the top $60 \mathrm{~m}$ of the water column as the majority of the copepod species analysed in this study reside within this depth horizon during summer (Atkinson et al. 1992, Ward et al. 1995). Minimum temperature in the upper $200 \mathrm{~m}$ gave an indication of the mixed layer temperature during the previous winter. Mixed layer depth (MLD) was included as a measure of water column stability, which might influence development of phytoplankton. The suggestion that krill may exert top-down control on copepod populations (Atkinson et al. 1999) was explored by using krill biomass acoustically determined within $5 \mathrm{~km}$ of the stations as a predictor variable.

Zooplankton community composition data for all 4 cruises were analysed using the Plymouth Routines in Multivariate Ecological Research (PRIMER) package. A species by station similarity matrix from the 4 cruises was constructed from the station-based zooplankton abundance data (ind. $\mathrm{m}^{-2}$ in 0 to $200 \mathrm{~m}$ ). To reduce the variability imparted by the less abundant taxa, those that contributed $<1 \%$ to the total were excluded (reducing the data set from 106 to 61 species stages and/or taxonomic categories). A square-root transformation was applied to reduce over-emphasis of the most abundant taxa and the data were then clustered.
Non-metric multidimensional scaling (MDS) was also applied to the data set and the significance of the resultant groupings, including year and station location, were tested using the non-parametric permutation procedure ANOSIM, to determine the test statistic $\mathrm{R}$ which lies in the range -1 to +1 . Where $\mathrm{R}=1$ all replicates within groups are more similar to each other than to any replicates from other groups. Conversely, where $\mathrm{R}=0$ similarities between and within groups will be approximately the same. On this basis the most appropriate groupings were identified and the SIMPER program (similarity percentages) was applied to disclose the taxa most responsible for similarity within as well as dissimilarity between groups.

Multivariate regressions using silicate, temperature, MLD, chl a and krill biomass as predictors of total copepod abundance were also performed to identify which best explained variation in copepod abundance.

\section{RESULTS}

\section{Female abundance and egg production rates}

Female abundance for both Rhincalanus gigas and Calanoides acutus was not significantly different between the $4 \mathrm{yr}$ of the survey (ANOVA: $R$. gigas, $F=2.68, \mathrm{p}=0.056 ; C$. acutus, $F=2.62, \mathrm{p}=0.061$ ). EPR of both species in relation to integrated chl $a$ measurements are presented (Fig. 2). A curvilinear relationship (Ivlev curve) gave the best fit and although noisy, the relationships were statistically significant. The data suggest egg production does not increase appreciably at chl a concentrations above $\sim 3 \mathrm{mg} \mathrm{m}^{-3}$ (0 to $60 \mathrm{~m}$ ). EPR ranged from 0 to 35 and 0 to 40 with a mean value of 11 and 10 eggs female ${ }^{-1} \mathrm{~d}^{-1}$ for $R$. gigas and C. acutus respectively. $g$ were in the order of 1 and $0.5 \%$ for $R$. gigas and C. acutus respectively (Table 1).

\section{Stage duration, carbon mass and mass specific growth rates}

Six species/stages were sufficiently abundant for detailed work on their physiology; Rhincalanus gigas stages CI to CIII, and Calanoides acutus stages CII to CIV. Three aspects of their growth and development were analysed, namely stage durations, $\mathrm{CM}$ and $g$. For stages where g data were not available only $\mathrm{CM}$ and its relationship with the predictor variables is reported.

Of the environmental factors included in our multiple regression analysis (see 'Data analysis' section above), silicate and mean temperature $(0$ to $60 \mathrm{~m})$ were the 
Table 1. Rhincalanus gigas and Calanoides acutus. Stage durations (SD, d) and confidence intervals (CI, 95\%) transformed to reciprocals to represent the range of stage durations in days, and mean juvenile and female mass specific growth rates $(g) \pm$ standard error (SE). Total number of individuals used for each determination are shown in parentheses. -: value not determined. NM: not observed moulting

\begin{tabular}{|c|c|c|c|c|}
\hline Copepodite stage & $\mathrm{SD}$ & $\mathrm{CI}$ & $g$ & SE \\
\hline \multicolumn{5}{|l|}{ Rhincalanus gigas } \\
\hline $\mathrm{CI}$ & 11 & 9-12 (1491) & 0.06 & \pm 0.008 \\
\hline CII & 18 & $13-22(2383)$ & 0.06 & \pm 0.009 \\
\hline CIII & 31 & $25-50(1904)$ & 0.04 & \pm 0.010 \\
\hline CIV & & - & - & \\
\hline $\mathrm{CV}$ & NM & $(400)$ & - & \\
\hline CVI female & & - & 0.011 & \pm 0.013 \\
\hline \multicolumn{5}{|l|}{ Calanoides acutus } \\
\hline $\mathrm{CII}$ & 5 & $4-5 \quad(547)$ & 0.24 & \pm 0.06 \\
\hline CIII & 8 & $8-10(2543)$ & 0.15 & \pm 0.01 \\
\hline CIV & 14 & $11-17(4021)$ & 0.14 & \pm 0.02 \\
\hline $\mathrm{CV}$ & NM & $(4000)$ & - & \\
\hline CVI female & & - & 0.005 & \pm 0.00 \\
\hline
\end{tabular}

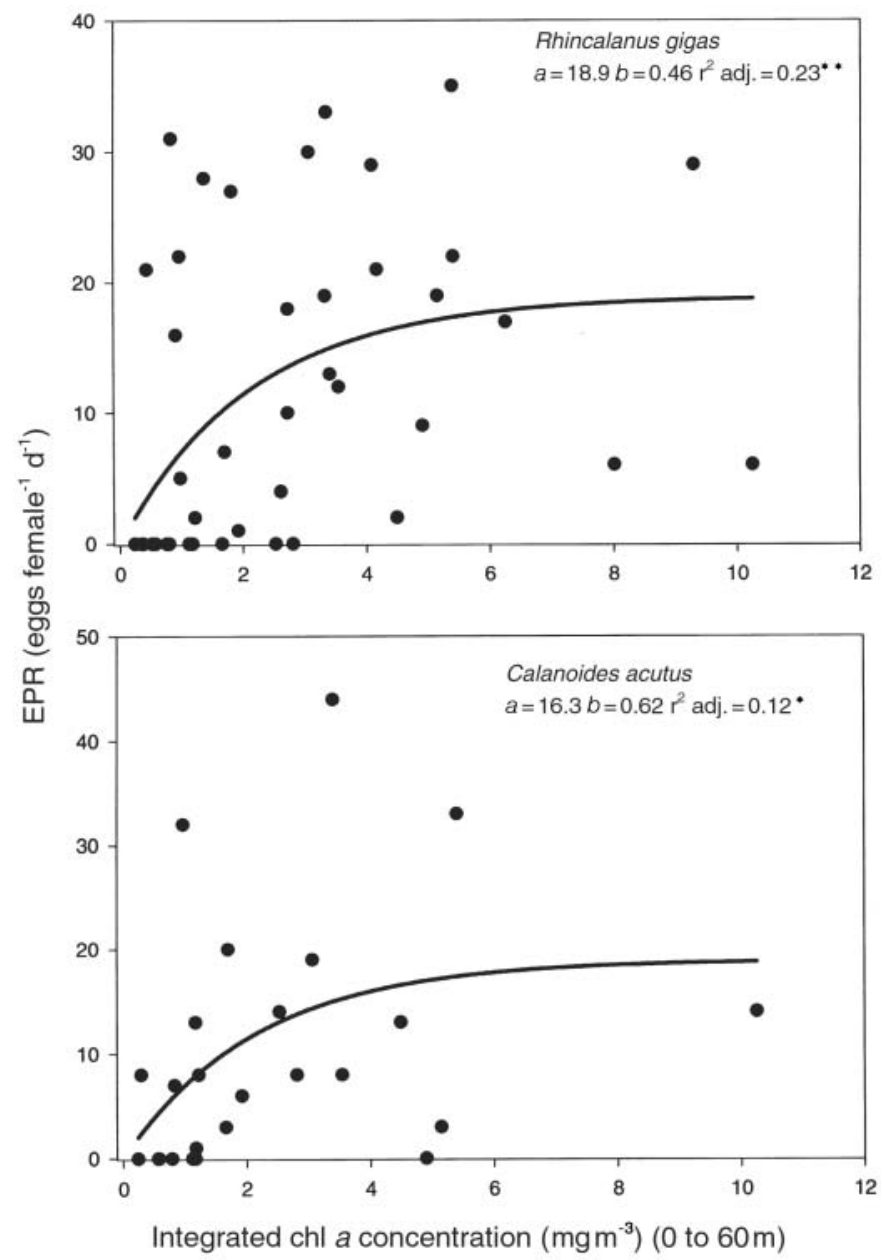

Fig. 2. Rhincalanus gigas and Calanoides acutus. Daily egg production rates (EPR, eggs female $\left.\mathrm{e}^{-1} \mathrm{~d}^{-1}\right)$ in relation to chl a concentration $\left(\mathrm{g} \mathrm{m}^{-2}, 0\right.$ to $\left.60 \mathrm{~m}\right)$. Ivlev curves fitted, EPR $=a\left(1-\mathrm{e}^{-b} \times c\right) .{ }^{*} \mathrm{p}<0.05,{ }^{* *} \mathrm{p}<0.005$ best predictors of stage duration, $\mathrm{CM}$ and growth. However, these 2 predictors were strongly negatively correlated (Fig. 3) $\left(\mathrm{r}^{2}\right.$ adj. $\left.=0.54, \mathrm{p}<0.0001\right)$ giving rise to instances in which one counter intuitively predicts variation in the response variable better than the other. For example, variation in CM was occasionally, but not systematically, better described by temperature than silicate. Such occurrences are likely to be spurious as although temperature and food may interact to determine growth, temperature principally acts to regulate stage duration (sensu Vidal 1980b) whereas food (silicate) should serve to regulate $\mathrm{CM}$, particularly in the later stages. We therefore only describe relationships with either temperature or silicate selecting the predictor variable that we feel confident has a sound physiological basis.

Stage durations and confidence intervals are summarised in Table 1. Stage duration was longer in Rhincalanus gigas than in equivalent stages of Calanoides acutus, and in both species it increased with ontogeny. Moulting was not observed in stage CV of either species during this survey. Development from stage CI to CIII took $\sim 2$ mo in $R$. gigas while $C$. acutus took $\sim 1$ mo from stage CII to CIV. Stage durations were not related to temperature. DM, CM and C:N mass ratio for $R$. gigas and C. acutus averaged over all the stations and years are given in Table 2. The proportion of CM to DM increased from $\sim 20 \%$ in the younger copepodite stages to $\sim 50 \%$ in the older lipid storing stages, the increased lipid composition of the latter is indicated in the higher $\mathrm{C}: \mathrm{N}$ ratio. Silicate best predicted CM for each species and stage, being significant in 8 out of 11 analyses (Fig. 4) and was generally a better predictor of $\mathrm{CM}$ in the younger copepodite stages.

$g$, which is defined as proportion of body carbon increase per day, is summarised in Table 1. g, was higher in the younger copepodite stages of both species, and was higher in Calanoides acutus in comparison to equivalent stages of Rhincalanus gigas. Growth was not significantly related to silicate or temperature in any of the stages studied, 
Table 2. Rhincalanus gigas and Calanoides acutus. Mean, with range shown in parentheses, of dry mass (DM, $\mu \mathrm{g})$, carbon mass $(\mathrm{CM}, \mu \mathrm{g})$, and carbon to nitrogen mass ratio (C:N). n: number of individuals used in each determination

\begin{tabular}{|lrcrc|}
\hline Copepodite stage & $\mathrm{n}$ & $\mathrm{DM}$ & $\mathrm{CM}$ & $\mathrm{C}: \mathrm{N}$ \\
\hline Rhincalanus gigas & & & & $6(3-7)$ \\
CI & 830 & $28(15-45)$ & $11(6-21)$ & $2.97(2.28-4.19)$ \\
CII & 2117 & $56(36-108)$ & $28(11-45)$ & $3.29-3.80)$ \\
CIII & 1466 & $113(66-171)$ & $75(33-145)$ & $3.81(2.46-4.53)$ \\
CIV & 472 & $285(197-422)$ & $560(159-1506)$ & $5.09(3.30-8.90)$ \\
CV & 671 & $1105(550-2529)$ & $1037(288-1791)$ & $6.38(4.00-8.40)$ \\
CVI female & 691 & $1997(642-3304)$ & & \\
Calanoides acutus & & & $4(2-5)$ & $3.43(3.20-3.89)$ \\
CII & 281 & $19(12-33)$ & $11(6-16)$ & $3.66(2.69-3.90)$ \\
CIII & 1396 & $48(24-116)$ & $176(15-54)$ & $3.87(2.60-5.98)$ \\
CIV & 2537 & $107(66-277)$ & $463(343-599)$ & $6.32(2.95-9.71)$ \\
CV & 2443 & $785(577-1012)$ & & $8.20(5.70-9.40)$ \\
CVI female & 368 & & & \\
\hline
\end{tabular}

although growth rates of the older copepodite stage of both species were lower.

\section{Copepod abundance}

Total copepod abundance varied approximately 30 -fold between stations over the 4 cruises (14 000 to 377000 ind. $\mathrm{m}^{-2}, 0$ to $200 \mathrm{~m}$ ) and was significantly and negatively related to silicate concentration (Fig. 5). Increases in abundance were not the result of increases of particular copepod taxa as the proportionate share of each grouping remained broadly the same (Table 3). Cluster analysis of net data across all 4 yr revealed 3 main station groupings with a single station remaining

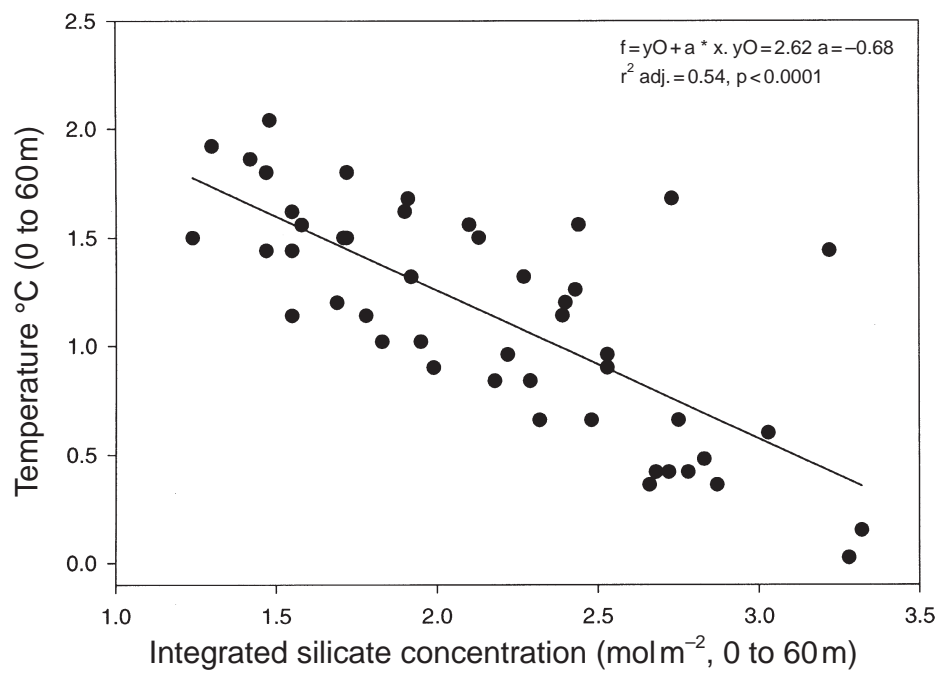

Fig. 3. Silicate concentration $\left(\mathrm{mol} \mathrm{m}{ }^{-2}, 0\right.$ to $60 \mathrm{~m}$ ) in relation to mean temperature $\left({ }^{\circ} \mathrm{C}, 0\right.$ to $\left.60 \mathrm{~m}\right)$. Solid line, least-squares regression unaccounted for by any of the main groupings (Fig. 6A). ANOSIM indicated that there were significant $(p<0.01)$ differences between the 4 station groups. Tests using year and station location, (on- or off-shelf, east and west) as a basis for grouping the data, or as additional factors in 2-way crossed and nested analyses, indicated only weak differences with respect to $\mathrm{R}$, and overall the initial separation was most robust (Table 4). It is possible for $\mathrm{R}$ to be significantly different from 0 yet be small as a result of the many replicates within each group, so attention should be focussed more on the value of $R$ than its significance. The data were further tested by SIMPER. This indicated that changes in the abundance of 2 main species, Oithona spp. and Ctenocalanus spp., were principally responsible for the similarities within as well as the dissimilarities between all groups (Table 5) (Group 4 had only 1 representative and so was omitted from this summary). MDS produced an ordination with low stress (0.1), indicating that the stations were well represented in 2-dimensional ordination space (Fig. $6 \mathrm{~B})$. Our analysis indicated that the zooplankton community was essentially the same across all years and regions, and the principal difference lay in the abundance of the major components, the species groups lay along a gradient with Group 1 being characterised by low abundance and Group 2 the highest (Fig. 7).

The environmental variables assumed a priori to link most closely to this ordination are shown as bubbleplot representations superimposed on the same ordination space (Fig. 7). The nature of the relationships between these 


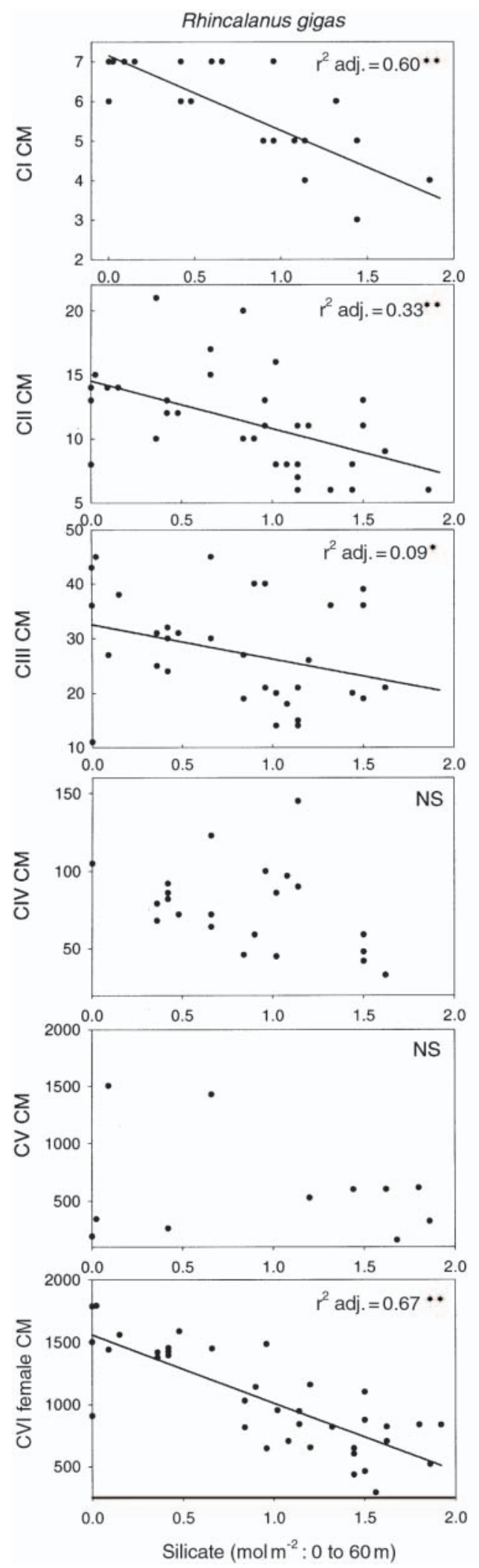

Calanoides acutus

No data
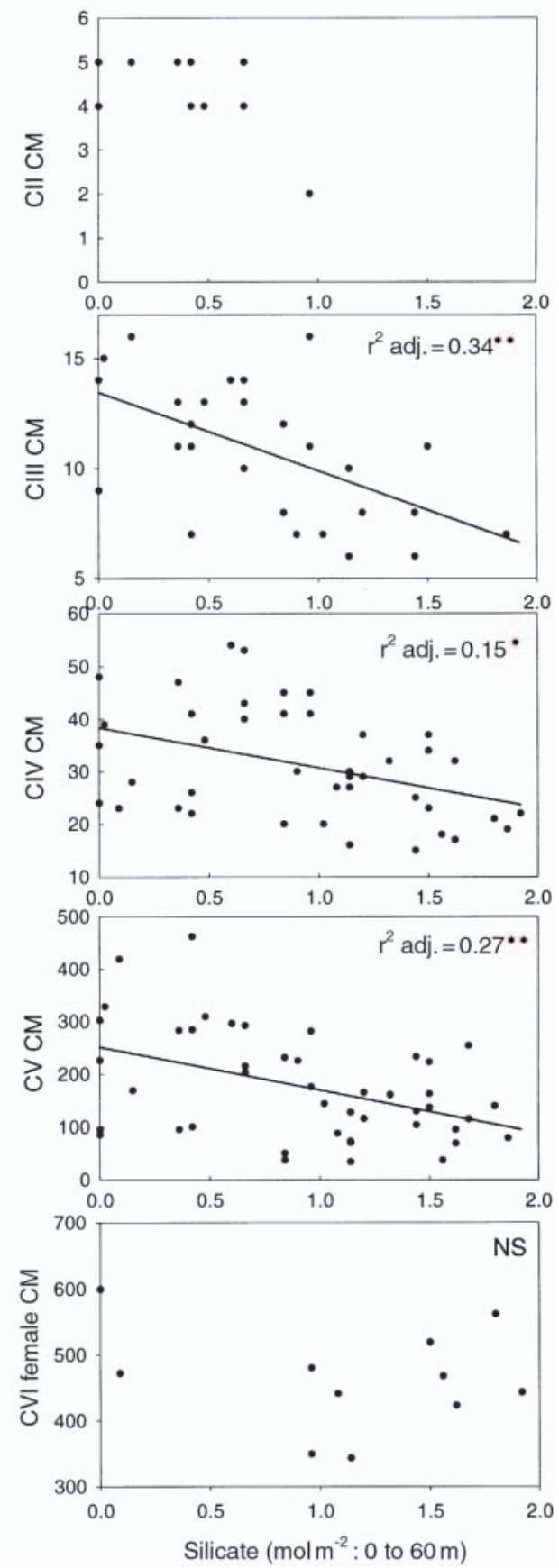

Fig. 4. Rhincalanus gigas and Calanoides acutus, mean carbon mass (CM, $\mu$ g) of each species stage in relation to silicate concentration (0 to $60 \mathrm{~m}$ ) simple least-squares regression line fitted, $\mathrm{r}^{2}$ adj. reported for each. ${ }^{* *} \mathrm{p}<0.001,{ }^{*} \mathrm{p}<0.01$ 


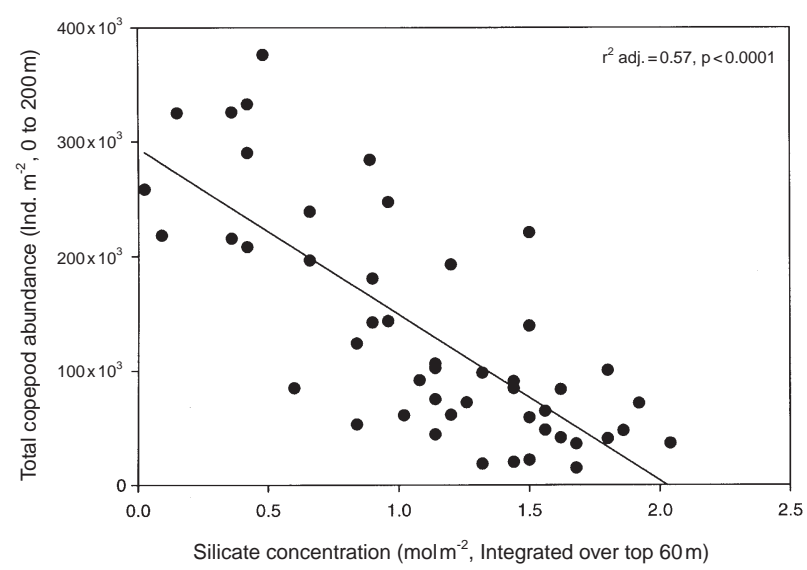

Fig. 5. Total copepod abundance (ind. $\mathrm{m}^{-2}, 0$ to $200 \mathrm{~m}$ ) in relation to integrated silicate $\left(\mathrm{mol} \mathrm{m}^{-2}, 0\right.$ to $\left.60 \mathrm{~m}\right)$. Solid line, least-squares regression

and total copepod abundance which is essentially driving the ordination can be clearly seen. Log transformation of the original species data matrix to further reduce the importance of abundant taxa followed again by clustering produced essentially the same story; a similar grouping of stations which MDS indicated was still a reasonable representation of the data (stress 0.17). ANOSIM confirmed significant differences between these station groups, which were again more robust than partitioning of the data in any other way, and which were again related to changes in abundance. SIMPER indicated that the differences between groups were now driven by different taxa, principally the younger stages of the biomass dominant species Rhincalanus gigas nauplii to stage CII, Calanus simillimus stages CI to CIII and Calanoides acutus stages CI to CIII.

Multiple least-squares regression analysis indicated that changes in the values of silicate most closely reflected changes in total copepod abundance with chl a improving the relationship to a small degree (Table 6).
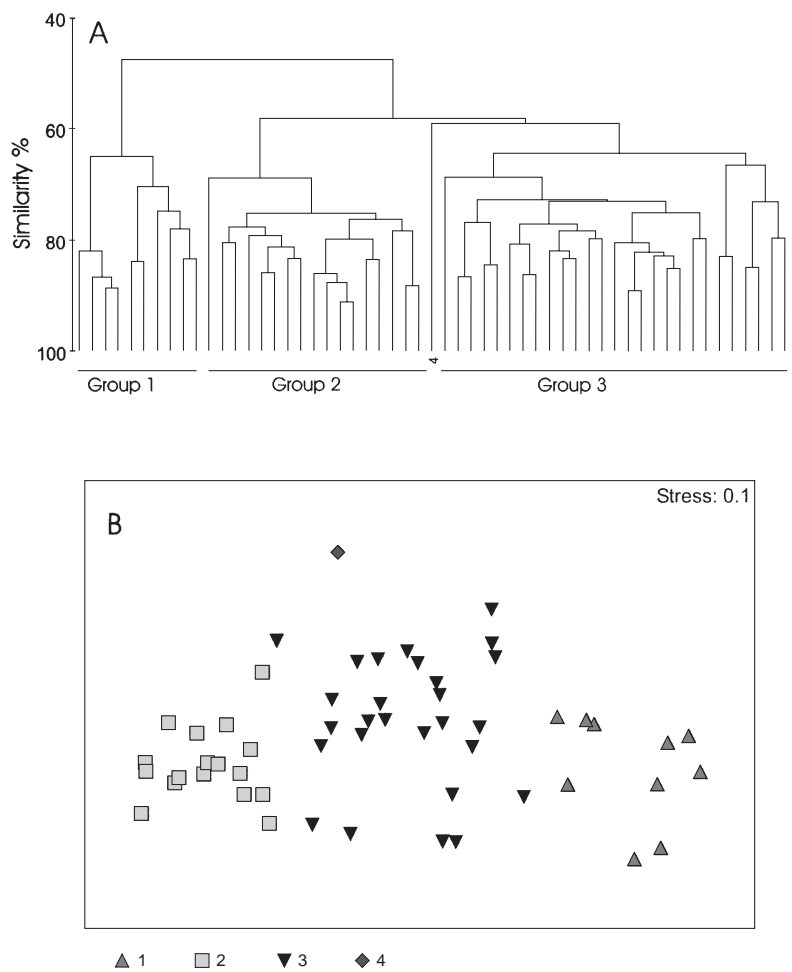

Fig. 6. (A) Results of Bray-Curtis similarity cluster analysis on the square-root-transformed zooplankton abundance matrix (see 'Materials and methods'). 'Station groups' (1 to 4) were arbitrarily designated based on a similarity level of $63 \%$. (B) MDS ordination of the square-root-transformed similarity matrix data coded as 'station groups' identified in the cluster analysis

Krill biomass was not significantly related to copepod abundance in this study. A similar pattern was found for the younger copepodite stages of Rhincalanus gigas (stages CI to CIII) and Calanoides acutus (stages CI to CIV) which would have been recruited during the current season (Table 6). Silicate again most closely

Table 3. Copepod species as a proportion of the total copepod abundance (TCA, \%), ind. $\mathrm{m}^{-2}$ to a depth of $200 \mathrm{~m}$. All copepodites stages of Oithona spp., Ctenocalanus spp., Metrida sp.; copepodite stages CI to CIII pooled for Rhincalanus gigas (Rg) and stages CI to CIV pooled for Calanoides acutus (Ca). Cumulative \% indicates the proportion that these 7 groups represent in the total copepod abundance

\begin{tabular}{|lcccccccc|}
\hline TCA & Oithona spp. & Ctenocalanus spp. & Metridia spp. & $\begin{array}{c}R g \text { CI } \\
\text { to CIII }\end{array}$ & $\begin{array}{l}R g \text { CIV } \\
\text { to CVI }\end{array}$ & $\begin{array}{c}\text { Ca CI } \\
\text { to CIV }\end{array}$ & $\begin{array}{c}C a \text { CV } \\
\text { to CVI }\end{array}$ & Cumulative \% \\
\hline $14000-120000$ & 68 & 12 & 8 & 1 & 3 & 0 & 1 & 94 \\
$120001-232000$ & 47 & 21 & 13 & 2 & 2 & 1 & 1 & 87 \\
$232001-320000$ & 54 & 20 & 17 & 3 & 2 & 1 & 1 & 88 \\
$320001-377000$ & 44 & 21 & 23 & 2 & 1 & 0 & 0 & 90 \\
\hline
\end{tabular}



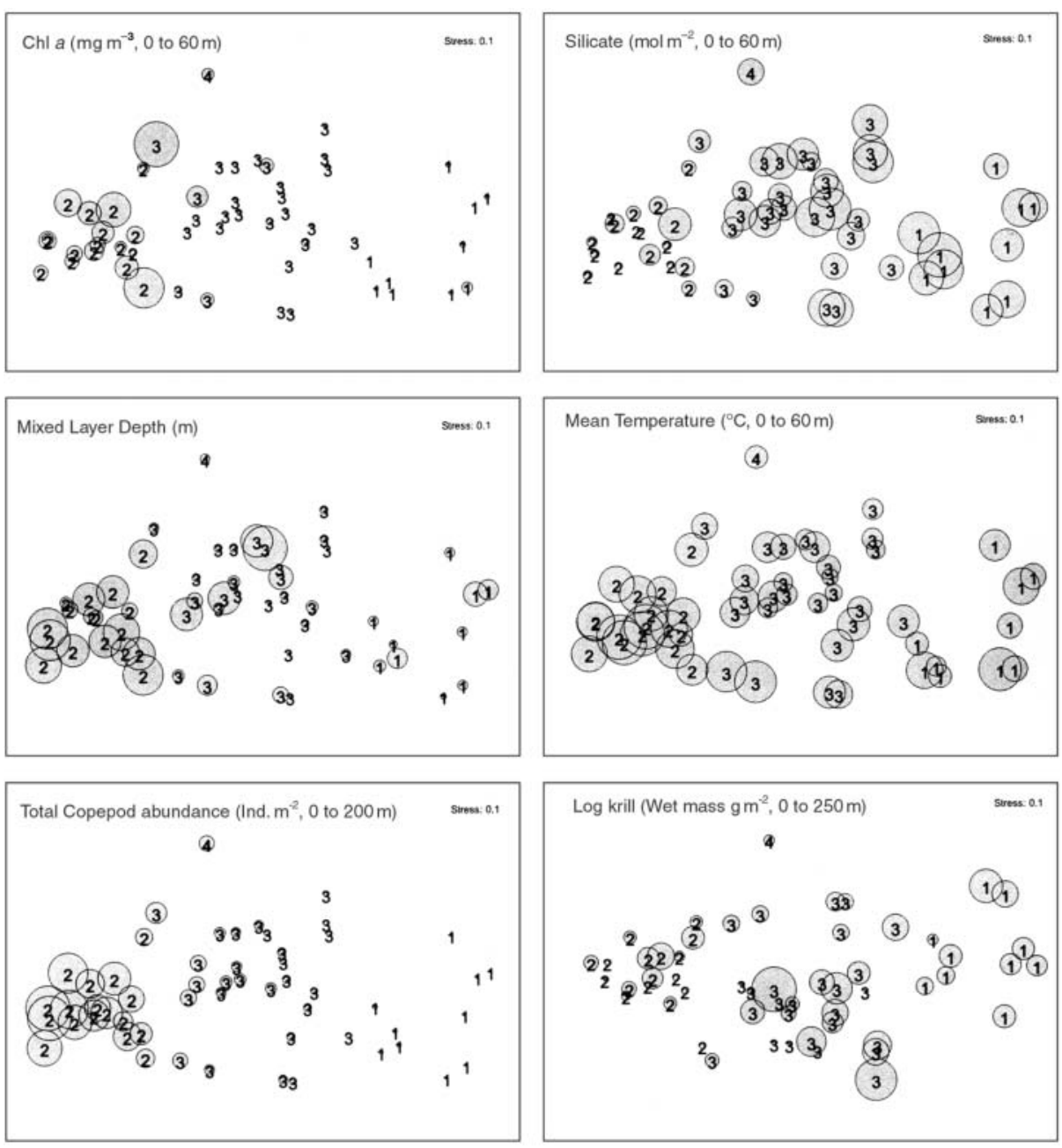

Fig. 7. Bubbleplot representations of copepod abundance and environmental factors which were tested as predictor variables of copepod abundance in the multiple regression analysis (see Table 6). Data have been superimposed on the 'stations groups' ordination space (see Fig. 6b) to clarify spatial relationships. The size of the bubbles are scaled to the minimum and maximum values for each variable; chl $a$ 0.24 to $10.25 \mathrm{mg} \mathrm{chl} \mathrm{a} \mathrm{m}^{-3}$ ( 0 to $60 \mathrm{~m}$ ), silicate 0.024 to $2.04 \mathrm{~mol}$ $\mathrm{m}^{-2}$ (0 to $\left.60 \mathrm{~m}\right)$, mixed layer depth 5 to $110 \mathrm{~m}$, mean temperature 1.24 to $3.32^{\circ} \mathrm{C}$ ( 0 to 60 $\mathrm{m})$, total copepod abundance 14594 to 376141 ind. $\mathrm{m}^{-2}$ (0 to $200 \mathrm{~m}$ ) and krill biomass 1.4 to $2111 \mathrm{~g} \mathrm{~m}^{-2}$ (0 to $\left.250 \mathrm{~m}\right)$
Table 4. Analysis of similarity (ANOSIM). Differences in the global R statistic with respect to different groupings of data within the species similarity matrix. Also given are the results of pairwise grouping within the 'station group' that showed the largest value of R. ${ }^{* * *} \mathrm{p}<0.001,{ }^{* *} \mathrm{p}<0.005,{ }^{*} \mathrm{p}>0.01$ and $\mathrm{p}>0.05$ (see text for details)

\begin{tabular}{|ll|}
\hline Grouping of data & Global R statistic \\
\hline Station groups & $0.828^{* * *}$ \\
Cruise & $0.385^{* * *}$ \\
East and west & $0.277^{* * *}$ \\
On- and off-shelf & $0.083^{*}$ \\
Station groups & R: pairwise tests \\
\hline 1,3 & $0.79^{* * *}$ \\
1,2 & $1.00^{* * *}$ \\
3,2 & $0.75^{* * *}$ \\
\hline
\end{tabular}

reflected the changes in abundance of the younger stages, with mean temperature improving the relationship. Krill biomass was again not significantly related to the abundance of these younger copepodite stages, although we would have anticipated that these stages would be most affected by the recent feeding conditions and would be under greater risk of predation by krill. Mean age of the population of $C$. acutus was significantly and positively related to silicate concentration (Fig. 8). This indicates that a younger population exists where there has been higher levels of primary production, suggesting higher recruitment in these areas. $R$. gigas did not show a relationship between mean age of the population and silicate; this is most likely because it overwinters as both stage CIII and CV (Ward et al. 1997), which serves to average the mean age of the population over 2 yr and hence cloud the picture of it against the current silicate concentrations. 
Table 5. Similarity percentages (SIMPER) carried out on the 3 main station groups identified in this study (Group 4 had only 1 representative and so was omitted from this summary). The mean abundance (no. ind. $\mathrm{m}^{-2}, 0$ to $200 \mathrm{~m}$ ) within species groups is given for the 5 species within each group that contribute most to the percentage similarity within that group. ( ( $)^{1}=$ number of samples within each species group. ( ) = rank order within each group. For each group 63 to $67 \%$ of the within group similarity was contributed by the first 5 ranked species. The proportion of dissimilarity between groups brought about by these species is in the range of 43 to $53 \%$. -: not ranked

\begin{tabular}{|lrrr|}
\hline 'Station groups' & $1(10)^{1}$ & $2(16)^{1}$ & $3(27)^{1}$ \\
\hline Oithona spp. & $23634(1)$ & $45164(1)$ & $49388(1)$ \\
Ctenocalanus sp. & $2174(2)$ & $48657(2)$ & $12044(2)$ \\
Metridia spp. CI to CIII & $544(3)$ & $33000(4)$ & $7908(3)$ \\
Chaetognatha & $370(4)$ & $689(-)$ & $401(10)$ \\
Copepod nauplii & $610(5)$ & $45164(3)$ & $4917(5)$ \\
Calanoides acutus CV & $193(11)$ & $3163(10)$ & $2254(4)$ \\
Rhincalanus gigas nauplii CII & $4(-)$ & $133(5)$ & $31(8)$ \\
Metridia spp. CIV to CVI & $11(14)$ & $78(-)$ & $3(6)$ \\
C. acutus CIV & $7(17)$ & $38(11)$ & $26(7)$ \\
\hline
\end{tabular}

\section{DISCUSSION}

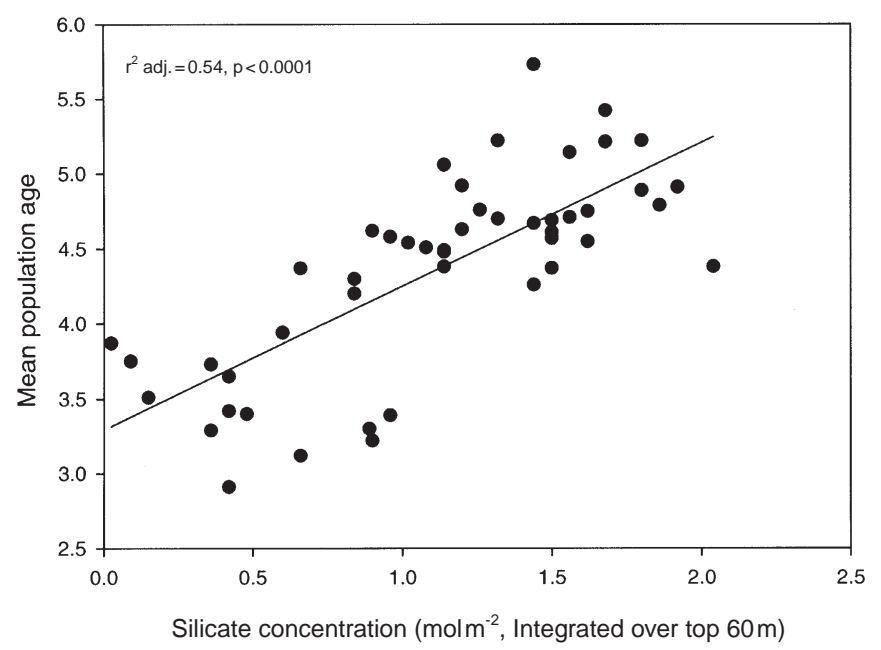

Fig. 8. Calanoides acutus. Mean age of the population in relation to integrated silicate concentration $\left(\mathrm{mol} \mathrm{m}^{-2}, 0\right.$ to $\left.60 \mathrm{~m}\right)$. Solid line, least-squares regression

\section{Egg production}

Egg production in both species was weakly but significantly related to ambient chlorophyll levels. The nature of this relationship will be influenced by the nutritive and size properties of the phytoplankton and also the physiological state of the female copepods. EPRs of Calanoides acutus measured by Lopez et al. (1993) during October/November in the Gerlache Strait were considerably higher than those recorded around South Georgia. The peak of spawning activity in this species takes place in late winter/early spring when females are newly moulted. By December/January, when our surveys took place, females comprise only a small proportion of the population and may be physiologically incapable of maintaining high EPRs. The December/January period does however represent the peak of recruitment for Rhincalanus gigas in the waters around South Georgia (Ward et al. 1997). Clearly what is indicated is that over much of the ACC for much of the time, food concentrations are likely to be limiting EPRs.

Table 6. Multiple regression analysis. Abundance of total copepods, Rhincalanus gigas stages CI to CIII and Calanoides acutus $\mathrm{CI}$ to CIV against predictor variables. $\mathrm{T}$ and $\mathrm{r}^{2}$ adj. values presented, ${ }^{* *} \mathrm{p}<0.005,{ }^{*} \mathrm{p}<0.05$, ns: not significant

\begin{tabular}{|lccc|}
\hline Predictor & Total copepods & R. gigas CI to CIII & C. acutus CI to CIV \\
\hline Silicate & $-3.13^{* *}$ & $-3.24^{* *}$ & $-5.24^{* *}$ \\
Krill $\left(\log _{10}+1\right)$ & $-1.03 \mathrm{~ns}$ & $-0.75 \mathrm{~ns}$ & $-1.32 \mathrm{~ns}$ \\
Temp $($ mean 0 to $60 \mathrm{~m})$ & $-0.45 \mathrm{~ns}$ & $-2.62^{* *}$ & $-5.24^{* *}$ \\
MLD & $1.52 \mathrm{~ns}$ & $0.59 \mathrm{~ns}$ & $0.56 \mathrm{~ns}$ \\
Chl $a(0$ to $60 \mathrm{~m})$ & $2.02^{*}$ & $1.27 \mathrm{~ns}$ & $1.70 \mathrm{~ns}$ \\
Analysis of variance adj. $\mathrm{r}^{2}$ & $0.61^{* *}$ & $0.36^{* *}$ & $0.57^{* *}$ \\
\hline
\end{tabular}




\section{Juvenile growth}

In contrast to the Antarctic krill Euphausia superba, very few direct or physiologically based growth rate estimates have been made on Southern Ocean copepods. Schnack et al. (1985) reported experimentally determined rates of ingestion, assimilation, respiration and indirectly estimated growth ( $\mu \mathrm{g} \mathrm{C}$ ind. $\mathrm{d}^{-1}$ ) for some of the biomass dominant copepods. These included measurements on Rhincalanus gigas and Calanoides acutus during early spring near the Antarctic Peninsula. Conversion of these data to $g$ gives extremely low estimates $(R$. gigas, 0.00028 to 0.0038 ; C. acutus, 0.0017 to 0.0038 ) (Conover \& Huntley 1991). As just about the only field estimate of copepod growth available from the Southern Ocean, until recently, the data of Schnack et al. (1985) have been used extensively in the formulation of global models of copepod growth (Huntley \& Lopez 1992, Hirst \& Sheader 1997) but as Conover \& Huntley (1991) have demonstrated, such rates generally predict generation times well in excess of those that can reasonably be inferred from the stage frequency data for either species (Atkinson et al. 1997, Ward et al. 1997). Growth rates presented here and by Shreeve \& Ward (1998) are in line with stage frequency data and confirm that development of the early stages can be rapid. Development from stage CI to CIII in Rhincalanus gigas and stage CII to CIV in Calanoides acutus took 60 and $27 \mathrm{~d}$ respectively. The lack of moulting in the stage CV copepodites is most probably due to them preparing for diapause. Extended durations in stage CV have also been observed in Calanus finmarchicus in natural populations during summer by Runge et al. (1985). There have been few direct field determinations of copepod growth and development; the vast majority of studies have been undertaken on laboratory populations reared under contrasting conditions of temperature and food (Harris \& Paffenhöffer 1976, Paffenhöffer \& Harris 1976, Vidal 1980a, Thompson 1982). However, our rates compare well with those determined by Corkett et al. (1986) for C. glacialis, where development from CI to CIV at $3^{\circ} \mathrm{C}$ in a laboratory reared population took $\sim 30 \mathrm{~d}$ (calculated from Corkett et al. 1986, their Fig. 3).

Although rates of advection through the region are poorly known, estimates of time taken to travel the length of the island $(200 \mathrm{~km})$ are $\sim 2$ mo on the northern shelf area compared to only 2 to $3 \mathrm{wk}$ in the faster jets off-shelf (FRAM Group 1991, Atkinson et al. 2001). It is therefore likely that copepod recruitment and growth will benefit considerably from any enhanced production around South Georgia. Phytoplankton blooms can also be advected considerable distances downstream of the island (Atkinson et al. 2001) and so it is probable that enhanced growth and recruitment will continue into otherwise oligotrophic oceanic waters.

We have also demonstrated that for the 2 species of Southern Ocean copepods considered here, $g$ within species are body mass dependent. While this appears to be a general rule (cf. Vidal 1980b, Hirst \& Sheader 1997, Richardson \& Verheye 1998), until now such data have been lacking for polar regions. Importantly, this study also highlights clear differences between the 2 species. Thus, the early stages of Calanoides acutus have growth rates that are some 2 to 3 times higher than Rhincalanus gigas, which is consistent with what we know about the metabolic demands of the 2 species. Thus, mass specific respiration rates (Schnack et al. 1985) and ingestion rates (Atkinson et al. 1992) of the older stages of $R$. gigas are reported to be lower than for $C$. acutus, which may well be due to the greater adult size of the former.

Whilst on a global scale, temperature is thought to be the main factor controlling growth rates (Huntley \& Lopez 1992), food limitation has also been shown to be important (Vidal 1980a, Kleppel et al. 1996). Although the growth rates determined in this study are broadly within the range predicted by several recent global models of copepod growth (Huntley \& Lopez 1992, Hirst \& Sheader 1997, Hirst \& Lampitt 1998), no systematic relationships were found for either species between $g$ and either temperature, chlorophyll or silicate. Many studies have demonstrated that stage duration in copepods is negatively related to temperature (e.g. Corkett \& McLaren 1970, Landry 1975, Vidal 1980b, Klein Breteler et al. 1982, Thompson 1982, Uye 1988); therefore, CM should increase at lower temperatures, assuming that food is not limiting. In older copepodite stages, growth is relatively less affected by temperature than is stage duration (Vidal 1980a). The lack of such clear relationships in our data is very probably due to; (1) the restricted range of field temperature over which growth was measured $\left(\sim 2^{\circ} \mathrm{C}\right)$; and (2) variation in available food. Previous work has demonstrated embryonic duration to be temperature dependent in both of these species, with a $2^{\circ} \mathrm{C}$ difference accounting for a 10 to $25 \%$ difference in egg hatching time (Ward \& Shreeve 1998). However, growth as determined in these experiments is a function of 2 components: stage duration and change in $\mathrm{CM}$. Both will be influenced by temperature and/or food but in different ways. Vidal (1980a) for instance found that growth of the younger stages of Calanus pacificus was optimised at higher temperatures, but for older stages food was more important.

Since we have found no systematic differences in stage duration within each stage in relation to temperature, we conclude that food, rather than temperature, was the major factor explaining variation in $\mathrm{CM}$ during 
the course of our study. As for copepod abundance, silicate depletion showed a stronger relationship with copepod carbon than ambient chlorophyll levels, indicating that past growth conditions were influential. When, as in this case, stage durations range in the order of 1 to $4 \mathrm{wk}$, we might expect there to be less of a 'fit' of CM with chlorophyll levels experienced at the time of sampling. However, relationships between $\mathrm{CM}$ and silicate were stronger for the youngest stages, reflecting perhaps a decreasing ability of silicate levels to accurately predict the $\mathrm{CM}$ of later stages. Additionally, females and the later stages (particularly of Rhincalanus gigas) may have overwintered, in which case conditions the previous year would be more important and a relationship with silicate would not be expected.

\section{Comparison of female and juvenile growth}

$g$ of females was much lower than measured in the younger copepodite stages. Egg production showed a curvilinear relationship with chlorophyll concentrations, suggesting food limiting conditions at the lower chlorophyll concentrations, but that above $\sim 3 \mathrm{mg}$ chl $a$ $\mathrm{m}^{-3}$ (0 to $60 \mathrm{~m}$ ), egg production reached maximum levels for this period of the year. Younger copepodite growth however appeared unaffected by food concentrations. Similar observations where in situ female egg production rates were not representative of the juvenile growth rates have also been reported for Calanus finmarchicus in the Skagerrak (Peterson et al. 1991).

Although juvenile growth appeared unaffected by food concentration, CM was significantly related in most cases (Fig. 4). However, as indicated above, growth is a product of both $\mathrm{CM}$ and stage duration. In this study, we found no significant difference in the stage duration in relation to either temperature or food, and although higher CMs were realised in individuals which had been exposed to higher standing stocks of chl $a_{\text {, }}$ the relative increase in body carbon $\mathrm{d}^{-1}$ was similar for all individuals of the same species and stage. $g$ decreased with progressively older stages for both species studied. This pattern is in agreement with growth data for Calanus agulhensis on the Agulhas bank (Peterson \& Hutchinson 1995) and C. pacificus in controlled laboratory experiments (Vidal 1980a).

In previous studies, egg production has often been used as a measure of juvenile growth (Hay 1995, McLaren \& Leonard 1995, Poulet et al. 1995), although McLaren \& Leonard (1995) caution the general use of this relationship without further verification. Peterson et al. (1991) condemned the use of female EPRs as a measure for juvenile growth, suggesting that in their study this assumption would have underestimated juvenile production by a factor of 2.7. Our study supports this cautionary note, as not only will the timing of the egg production studies in relation to the peak of female production affect estimates, but progressively younger copepodite stages have a higher $g$, making their relationships with egg production variable.

\section{Environment}

There was considerable variation in all physical, chemical and biological parameters measured during the present study. Such heterogeneity is a feature of the South Georgia system and has been described previously for hydrography and nutrients (cf. Deacon 1933, Whitehouse 1997), phytoplankton (cf. Hart 1934, Priddle et al. 1986) and zooplankton (cf. Hardy \& Gunther 1935, Atkinson 1989). Variation in phytoplankton abundance and nutrient distribution has been attributed to a number of scale-related causes, e.g. the large-scale influence of different water masses and fronts, mesoscale variability due to shelf-break processes, and the small-scale effects due to phytoplankton productivity and differential nutrient preferences (Whitehouse et al. 1993).

Deacon (1977) identified further environmental variability at South Georgia when he documented distinctly colder and warmer years around the island and linked them to variations in ice cover further south. Using fast-ice duration data from the South Orkneys, Murphy et al. (1995) and Whitehouse et al. (1996) demonstrated a correlation between South Georgia surface measurements and the duration/extent in the southern Scotia Sea (negative for temperature and positive for silicate). They suggest that the cooler summers described by Deacon may be a result of basin scale cooling associated with sea-ice extent and duration as opposed to a broad shift in water mass distribution.

There was no indication of the presence of different water masses around the island during the present study, apart from some locally physically modified water present on the island shelf (Brandon et al. 1999, 2000); all else was characteristic of ACC waters. Therefore, temperature change thus appeared to be driven by seasonality, with annual large-scale variability due to factors other than water mass change. Nutrient variation (silicate depletion) on the other hand appeared to be due to small-scale processes associated with phytoplankton production.

\section{Factors affecting copepod populations}

In a previous study in this region, Atkinson et al. (1999) demonstrated an inverse relationship between krill and 
copepod abundance over a range of scales. They suggested that this was likely due to predation of copepods by krill, although did not rule out the possibility of differences in the physical environment or of the timing of the phytoplankton bloom as being more important. In this study, a stronger relationship was found between total copepod abundance and silicate than with krill (Fig. 5, Table 6), leading us to incline to the view that over the $4 \mathrm{yr}$, timing of the bloom and environment rather than krill predation were the more important factors. The facts that EPRs of both Rhincalanus gigas and Calanoides acutus were food limited over much of the survey period (Fig. 2) and the abundance of their younger copepodite stages (Table 6) and the mean age of the $C$. acutus population, which were all strongly related to silicate (Fig. 8), also supports this view.

Mortality from all sources is difficult to quantify in field data of this sort. It is ever present and there are obvious difficulties in assessing the role of krill predation as a factor shaping population dynamics, not least because, unlike silicate which acts as a conservative proxy for past production, krill distribution is variable in time and space. However, inter-annual variations in abundance of krill can be particularly marked (Brierley et al. 1997) and Trathan et al. (unpubl.) have noted an inverse relationship between temperature and the presence of krill. Their suggestion that krill are abundant in the southern part of the ACC and that increased abundance around South Georgia reflects a northwards extent of this colder water towards the island is in agreement with current ideas of krill transport across the Scotia Sea (Marr 1962, Hofmann et al. 1998) and with the basin scale variability alluded to by Whitehouse et al. (1996).

As a higher biomass of krill prevailed in colder water, the associated low chlorophyll concentrations may be a result of competitive effects of krill grazing. Grazing pressure may keep phytoplankton growth in check, and/or potentially alter the species composition of the phytoplankton community (Granéli et al. 1993). Alternatively, as we suggest, low chlorophyll concentrations may be due to sub-optimal growth of phytoplankton at low temperatures. The higher silicate concentrations associated with colder water suggest that phytoplankton growth around South Georgia is limited by either low temperature or some allied factor. Reay et al. $(1999,2001)$ report a tripling in phytoplankton growth rate when temperature was raised between 3 and $6^{\circ} \mathrm{C}$ above the ambient seawater temperature, ascribing these large differences in production to the reduced ability of micro-algae to actively utilise nutrients at the lower temperatures. Southern Ocean phytoplankton are generally psychrotolerant, with the temperature optima for growth being in excess of those they usually encountered (Tilzer et al. 1986, Smith \&
Harrison 1991). The temperature range of $\sim 2^{\circ} \mathrm{C}$ that we experienced in our studies could therefore underlie the differences in copepod abundance we observe. Our current findings tend to support the ideas that copepod abundance and biomass in the South Georgia marine ecosystem are most likely controlled by 'bottom-up' mechanisms, principally driven by largescale fluctuations in temperature.

\section{CONCLUSIONS}

Although $g$ and stage duration of Rhincalanus gigas and Calanoides acutus showed no systematic relationships to any of the concurrently measured environmental factors, CM of most species stages was negatively related to silicate concentrations, indicating the role of past phytoplankton production in determining body mass. Growth rates for both species fitted well with current global models of copepod growth and data supported the concept of mass dependent growth.

An ordination of zooplankton species occurrence by station across the 4 summer surveys indicated that changes in abundance were more pronounced than changes in species composition. The same taxa in broadly the same proportions occurred irrespective of abundance and furthermore, abundance was strongly related to past primary production rather than the presence of krill.

Krill at South Georgia were more abundant in colder, silicate-rich waters and their presence is presumed to be governed by factors operating at the large scale. In contrast, copepod abundance appears to differ in response to smaller-scale variation in the environment and appeared to be linked through silicate to factors determining phytoplankton growth.

This study is a clear demonstration that factors regulating the abundance, growth and development of phytoplankton, mesozooplankton and krill at South Georgia overlap across different temporal and spatial scales.

Acknowledgements. We would like to thank the officers and crew of the RRS 'James Clark Ross' and our colleagues within the DYNAMOE programme for their assistance in the field. Dr. M. Brandon provided data on the physical oceanography, and Drs. J. Priddle and A. Brierley data on chlorophyll and krill biomass respectively. Comments by Drs. M. Meredith and A. Atkinson, and 3 anonymous referees considerably improved the manuscript.

\section{LITERATURE CITED}

Atkinson A (1989) Distribution of six major copepod species around South Georgia in early summer. Polar Biol 9: 353-363 
Atkinson A, Snÿder R (1997) Krill-copepod interactions at South Georgia, Antarctica, I. Omnivory by Euphausia superba. Mar Ecol Prog Ser 160:63-76

Atkinson A, Ward P, Williams R, Poulet SA (1992) Feeding rates and diel vertical migration of copepods near South Georgia: comparison of shelf and oceanic sites. Mar Biol 114:49-56

Atkinson A, Schnack-Schiel SB, Ward P, Marin V (1997) Regional differences in the life cycle of Calanoides acutus (Copepoda: Calanoida) within the Atlantic sector of the Southern Ocean. Mar Ecol Prog Ser 150:99-111

Atkinson A, Ward P, Hill A, Brierely AS, Cripps C (1999) Krill-copepod interactions at South Georgia, Antarctica, II. Euphausia superba as a major control on copepod abundance. Mar Ecol Prog Ser 176:63-79

Atkinson A, Whitehouse MJ, Priddle J, Cripps GC, Ward P, Brandon MA (2001) South Georgia, Antarctica: a productive, cold water, pelagic ecosystem. Mar Ecol Prog Ser 216:279-308

Brandon MA, Murphy EJ, Whitehouse MJ, Trathan PN, Murray AWA, Bone D, Priddle J (1999) The shelf-break front to the east of the sub-antarctic island of South Georgia. Cont Shelf Res 19:799-819

Brandon MA, Murphy EJ, Trathan PN, Bone DG (2000) Physical oceanographic conditions to the northwest of the sub-Antarctic island of South Georgia. J Geophys Res 105:23983-23996

Brierley AS, Watkins JL, Murray AWA (1997) Interannual variability in krill abundance at South Georgia. Mar Ecol Prog Ser 150:87-98

Brierley AS, Watkins JL, Goss C, Wilkinson MT, Everson I (1999) Acoustic estimates of krill density at South Georgia, 1981 to 1998 . CCAMLR Sci 6:47-57

Conover RJ, Huntley ME (1991) Copepods in ice covered seas - distribution, adaptations to seasonally limited food, metabolism, and growth patterns and life cycle strategies in polar seas. J Mar Syst 2:1-41

Corkett CJ, McLaren IA (1970) Relationships between development rate of eggs and older copepodite stages of copepods. J Mar Biol Assoc UK 50:161-168

Corkett CJ, McLaren IA, Sevigny JM (1986) The rearing of the marine calanoid copepods Calanus finmarchicus (Gunnerus), C. glacialis Jaschnov and C. hyperboreus Kroyer with comment on the equiproportional rule. In: Schriever G, Schminke HK, Shih CT (eds) Proc 2nd Int Conf on Copepoda. Syllogeus, Vol. 58. National Museums of Canada, Ottawa, p 539-546

Deacon GER (1933) A general account of the hydrography of the South Atlantic Ocean. Discovery Rep 7:171-238

Deacon GER (1977) Seasonal and annual variations in the water temperature and salinity near South Georgia 1925-1937. Institute of Oceanographic Sciences Report No. 49, Wormley

FRAM (Fine Resolution Antarctic Model) Group (1991) Initial results from fine-resolution model of the Southern Ocean. EOS, Trans AM Geophys Union 72:174-175

Granéli E, Granéli W, Rabbani MM, Daubjerg N, Franz G, Cuzin Roudy J, Alder VA (1993) The influence of copepod and krill grazing on the species composition of phytoplankoton communities from the Scotia-Weddell an experimental approach. Polar Biol 13:201-213

Hardy AC, Gunther ER (1935) The plankton of the South Georgia whaling grounds and adjacent waters, 1926-27. Discovery Rep 11:1-456

Harris RP, Paffenhöfer GA (1976) Feeding, growth and reproduction of the marine planktonic copepod Temora longicornis Müller. J Mar Biol Assoc UK 56:675-690

Hart TJ (1934) On the plankton of the south west Atlantic and the Bellingshausen Sea 1929-31. Discovery Rep $8: 1-268$

Hay S (1995) Egg production and secondary production of common North Sea copepods: field estimates with regional and seasonal comparisons. ICES J Mar Sci 52:315-327

Hirst AG, Lampitt RS (1998) Towards a global model of in situ weight-specific growth in marine planktonic copepods. Mar Biol 132:247-257

Hirst AG, Sheader M (1997) Are in situ weight specific growth rates body size independent in marine planktonic copepods? A re-analysis of the global synthesis and a new empirical model. Mar Ecol Prog Ser 154:155-165

Hofmann EE, Klink JM, Locarnini RA, Fach B, Murphy E (1998) Krill transport in the Scotia Sea and environs. Antarct Sci 10:406-415

Huntley ME, Lopez DG (1992) Temperature-dependent production in marine copepods: a global synthesis. Am Nat 140:201-242

Huntley ME, Niiler P (1995) Physical control of population dynamics in the Southern Ocean. ICES J Mar Sci 52:457-468

Klein Breteler WCM, Franz HG, Gonzalez SR (1982) Growth and development of four calanoid copepod species under experimental and natural conditions. Neth J Sea Res 16:195-207

Kleppel GS, Davis CS, Carter K (1996) Temperature and copepod growth in the sea: a comment on the temperaturedependant model of Huntley and Lopez. Am Nat 148: 397-406

Landry MR (1975) The relationship between temperature and the development of life stages of the marine copepod Acartic clausi Giesbr. Limnol Oceanogr 20:854-858

Longhurst AR (1998) Ecological geography of the sea. Academic Press, San Diego CA

Lopez DG, Huntley ME, Lovette JT (1993) Calanoides acutus in Gerlache Strait, Antarctica. I. Distribution of late copepodite stages and reproduction during spring. Mar Ecol Prog Ser 100:153-165

Mackintosh NA (1934) Distribution of the macroplankton in the Atlantic sector of the Antarctic. Discovery Rep 9:65-160

Marr JWS (1962) The natural history and geography of the Antarctic krill (Euphausia superba Dana). Discovery Rep 32:33-464

McLaren IA, Leonard A (1995) Assessing the equivalence of growth and egg production of copepods. ICES J Mar Sci 52:397-408

Murphy EJ, Clarke A, Symon C, Priddle J (1995) Temporal variation in Antarctic sea-ice: analysis of a long term fast-ice record from the South Orkney Islands. Deep-Sea Res Part I 42(7):1045-1062

Neave HR (1981) Elementary statistical tables. George Allen \& Unwin, London

Orsi AH, Whitworth T, Nowlin WD (1995) On the meridional extent and fronts of the Antarctic Circumpolar current. Deep-Sea Res 42:641-673

Paffenhöfer GA, Harris RP (1976) Feeding, growth and reproduction of the marine planktonic copepod Psuedocalanus elongatus. J Mar Biol Assoc UK 56:327-344

Parsons TR, Maita Y, Lalli CM (1984) A manual of chemical and biological methods for seawater analysis. Pergamon Press, Oxford

Peterson WT, Hutchings L (1995) Distribution, abundance and production of the copepod Calanus agulhensis on the Agulhas Bank in relation to spatial variations in hydrography and chlorophyll concentration. J Plankton Res 17:2275-2294

Peterson WT, Tiselius P, Kiørboe T (1991) Copepod egg 
production, moulting and growth rates, and secondary production, in the Skagerrak, in August 1988. J Plankton Res 13:131-154

Poulet SA, Ianora A, Laabir M, Klein Breteler WCM (1995) Towards the measurement of secondary production and recruitment in copepods. ICES J Mar Sci 52:359-368

Priddle J, Heywood RB, Theriote E (1986) Some environmental factors influencing phytoplankton in the Southern Ocean around South Georgia. Polar Biol 5:65-79

Reay DS, Nedwell DB, Priddle J, Ellis-Evans JC (1999) Temperature dependence in inorganic nitrogen uptake: reduced affinity for nitrate at suboptimal temperatures in both algae and bacteria. Appl Environ Microbiol 65: $2577-2584$

Reay DS, Priddle J, Nedwell DB, Whitehouse MJ, Ellis-Evans JC, Deubert C, Connelly DP (2001) Regulation by low temperature of phytoplankton growth and nutrient uptake in the Southern Ocean. Mar Ecol Prog Ser 219:51-64

Richardson AJ, Verheye HM (1998) The relative importance of food and temperature to copepod egg production and somatic growth in the southern Benguela upwelling system. J Plankton Res 20:2379-2399

Runge JA, McLaren IA, Corkett CJ, Bohrer RN, Koslow JA (1985) Molting rates and cohort development of Calanus finmarchicus and C. glacialis in the sea off southwest Nova Scotia. Mar Biol 86:241-246

Schnack SB, Smetacek V, Bodungen BV, Stegmann P (1985) Utilisation of phytoplankton by copepods in antarctic waters during spring. In: Gray JS, Christiansen ME (eds) Marine biology of polar regions and effects of stress on marine organisms. John Wiley \& Sons, Chichester, p 65-81

Shreeve RS, Ward P (1998) Moulting and growth of the early stages of two species of Antarctic calanoid copepod in relation to differences in food supply. Mar Ecol Prog Ser 175:109-119

Smith WO, Harrison WG (1991) New production in polar regions: the role of environment controls. Deep-Sea Res 38:1463-1479

Thompson B (1982) Growth and development of Pseudocalanus elongatus and Calanus sp. in the laboratory. J Mar Biol Assoc UK 62:359-372

Thorpe SE, Heywood KJ, Brandon MA, Stevens DP (in press) Variability of the Southern Antarctic Circumpolar Current north of South Georgia. J Mar Syst

Tilzer MM, Elbrächter M, Gieskes WW, Beese B (1986) Lighttemperature interactions in the control of photosynthesis in Antarctic phytoplankton. Polar Biol 5: 105-111

Tréguer P, Jacques G (1992) Dynamics of nutrients and

Editorial responsibility: Otto Kinne (Editor),

Oldendorf/Luhe, Germany phytoplankton, and fluxes of carbon, nitrogen and silicon in the Antarctic Ocean. Polar Biol 12:149-162

Uye SI (1988) Temperature-dependant development and growth of Calanus sinicus (Copepoda: Calanoida) in the laboratory. Hydrobiologia 167/168:285-293

Vidal J (1980a) Physioecology of zooplankton. I. Effects of phytoplankton concentration, temperature, and body size on the growth rate of Calanus pacificus and Pseudocalanus sp. Mar Biol 56:111-134

Vidal J (1980b) Physioecology of zooplankton. II. Effects of phytoplankton concentration, temperature, and body size on the development and moulting rates of Calanus pacificus and Pseudocalanus sp. Mar Biol 56:135-146

Ward P, Shreeve RS (1995) Egg production in three species of Antarctic calanoid copepods during an austral summer. Deep-Sea Res 42:721-735

Ward P, Shreeve RS (1998) Egg hatching times of Antarctic copepods. Polar Biol 19:142-144

Ward P, Atkinson A, Peck JM, Wood AG (1990) Euphausiid life cycles and distribution around South Georgia. Antarct Sci 2:43-52

Ward P, Atkinson A, Murray AWA, Wood AG, Williams R, Poulet SA (1995) The summer zooplankton community at South Georgia: biomass, vertical migration and grazing. Polar Biol 15:195-208

Ward P, Shreeve RS, Cripps GC, Trathan PN (1996) Mesoscale distribution and population dynamics of Rhincalanus gigas and Calanus simillimus in the Antarctic Polar Open Ocean and Polar Frontal Zone during summer. Mar Ecol Prog Ser 140:21-32

Ward P, Atkinson A, Schnack-Schiel SB, Murray AWA (1997) Regional variation in the life cycle of Rhincalanus gigas (Copepods: Calanoida) in the Atlantic sector of the Southern Ocean- re-examination of existing data (1928-1993) Mar Ecol Prog Ser 157:261-275

Whitehouse MJ (1997) Automated seawater nutrient chemistry. British Antarctic Survey Report, Cambridge

Whitehouse MJ, Symon C, Priddle J (1993) Variations in the distribution of chlorophyll $a$ and inorganic nutrients around South Gerogia, South Atlantic. Antarct Sci 5:367-376

Whitehouse MJ, Priddle J, Symon C (1996) Seasonal and annual change in seawater temperature, salinity, nutrient and chlorophyll a distribution around South Georgia, South Atlantic. Deep-Sea Res 43:425-443

Whitehouse MJ, Priddle J, Brandon MA (2000) Chlorophyll/ nutrient characteristics in the water masses to the north of South Georgia, Southern Ocean. Polar Biol $23: 373-382$

Submitted: July 6, 2001; Accepted: November 1, 2001

Proofs received from author(s): April 15, 2002 